定にして) 検討して発表されたい。

2. Exotoxin としてのS L O、S L S、との関係 を追求していただきたい。

\section{4. 口腔領域における好塩菌の研究}

（口紐）。待山弥彦、池田敏昭

近海漁業の盛んな、長崎、佐世保両地域を中心とし た接客業の健康人口腔唾液より、B－T．B．培地を用 いて好塩菌の検出を試みたが、260例よりは、菌の㭘 出は出来なかつた。しかし、B．T.B．培地上に発育 したグラム除性桿菌 7 株を得た。この菌株は、いずれ む、 $7 \% \mathrm{NaCl}$ 加ペプトン水化て発育良好であるが、 10\% $\mathrm{NaCl}$ 加のペプトン水の場合には、その中、5 株 の発育をみた。他の性状注検討中である。

\section{「5. 口腔領域分離の「ブ」球菌について}

$$
\text { (口紐)大和 健 一 }
$$

口腔領域の種々の材料（䨑槽膿漏52例〜13株（25\% ）、歯踨膿癔41列〜33株（80\%）、唾液16列～13株（ $81 \%)$ 、感染根管88例～37株 (45\%)） 197例より96 株（48.7\%) のブ球菌を検出した。乙れを Bergeyの 分類に比較すると Sta. aureus は 8 株、Sta. epidermidis は68株で他の20株はマンニツト分解能 (十)、 血獎凝固能（一） D19株とマンニツト分解能（一）、 血等凝固能 (十)の1株計20株があつた。

110培地に打ける培養試験では Sta. epicermidis 株の中の 4 株と他の28株が旺盛な発育を呈した。

更にこの32菌株について、昭和感受性デイスク 6 種 を用いて薬剤感受性試験を追試した。

すなわら、クロラムフェニコール、エリスロマイシ ンが感受性強く、ついでストレプトマイシンであつた ペニシリン、テトラサイタリン、スルフィイキゾール では、抵抗性の菌株が多く、㕛症例别による感受性 度の差はなかっつた。

\section{質 疑 (絧菌) 徳永純一}

Bergey の分類によると genus Micrococcus と genus Staphylococcus との分類を充分に検討しな いと、Staphylococcus aureus、Staphylococcus epidermidis に一致しない strain が多くなりすぎ てこまると思いますので先づその検討を充分てやつて いただきたい。

\section{6. ブ球菌毒素に関する研究}

(口細) 内山長司、大中文太郎

畨槽膿瘍より分離の Sta. aureusを用いて家鬼の

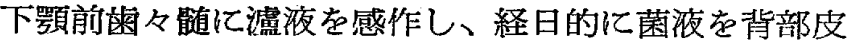
内に接種し、蒾牙組織の X線処見及び背部接種部の変 化を観察したが、変化はなかつた。

しかし、家象の背部皮内菌液を感作し、経日的に 瀘液を下顎前雪雪䙉に接種した場合は歯牙組織のX線 処見に変化はなかつたが背部接種部、及び耳翼の著明 な発赤と、眼瞼に充血を呈した。文、これらの反応は 90分後完全に消失した。本現象について何であるか、 実験を重ね追求している。

\section{7. 口腔由来の非定型抗酸菌に関する研究}

（第 2 報）

(口細) 塩田 豊、塊塚正隆

口腔領域疾患者の歯石より非定型酸菌の分離を試み た。すなわち、歯䶜炎46例、荬槽膿漏 175 例、健康口 腔の菡石19例、計 240 例より L6venstein、住吉法、 で前処定し、Kirchner 培地に増菌し、岡・片倉培地 に培養して検出に努めたが今回の検出成績は、のであ つた。

\section{質 疑 (口䋖) 大曲}

前回の発表の際に泣前処理は住吉 Lovenstein 法 を採用して $4 \%$ 検出率を得ていた。今回は Naorn 前処理により264例を行い0\%である。

余りに検出が悪いのを不番に思うので更に培養操作 を変えて、研究続行の予定である。

28. 中 止

\section{Candida albicans $の$ chlamydospore の微細構造について}

(絊菌)。德永純一、秋貞泰輔

病原性真菌 Candida albicans 以下 C. alb. と 略す) の Blastospore、pseudomycelium 等の細胞 微細棈造に関する研究は数多いが、chlamydospore に関するすのは非常に数少い。我々の教室では特䛈な 培養方法によつて chlamydospore を多数形成させ 得るようになつたので、この方法によつて得た chlamydospore について光顕的に得た色々の成績を発表 して来たが、今回怯特にその㸡紐構造を電子顕微鏡的 に追求し得た2、3の知見について報告する。 